\title{
Bee careful! Conflict between beekeepers and giant armadillos (Priodontes maximus) and potential ways to coexist
}

\author{
Arnaud L.J. Desbiez ${ }^{A, B, C, 1}$, Bruna Oliveira $^{A}$ \& Mariana Labão Catapani ${ }^{A, D}$ \\ A Instituto de Conservação de Animais Silvestres (ICAS), Rua Afonso Lino Barbosa, 142, Chácara Cachoeira, 79040-290, \\ Campo Grande, Mato Grosso do Sul, Brasil

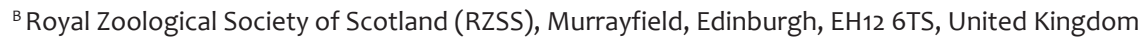 \\ 'Instituto de Pesquisas Ecológicas (IPÊ), Rodovia Dom Pedro I, km 47, 12960-000, Nazaré Paulista, São Paulo, Brasil \\ DPost-Graduate Program in Environmental Science, Institute of Energy and Environment, University of São Paulo, \\ Av. Prof. Luciano Gualberto, 1289, CEP 05508-010, São Paulo, Brazil
}

'Corresponding author. E-mail: adesbiez@hotmail.com

\begin{abstract}
Damage caused by wildlife is one of the main causes of human-wildlife conflict (HWC) worldwide and poses a significant threat to both biodiversity conservation and human livelihoods. Understanding the mechanisms that underpin such damage is critical to tackle HWC and foster coexistence. In this paper we provide information on the pattern and magnitude of damage by giant armadillos (Priodontes maximus) to apiaries in the Cerrado biome of Mato Grosso do Sul, Brazil. With the collaboration of 10 beekeeping associations we gathered information from 178 beekeepers. Seventy-three percent of these individuals reported beehive damage by giant armadillos in the last five years and $46 \%$ in the last 12 months, resulting in substantial economic losses. We used a combination of beekeepers' reports and camera traps to characterize the pattern of damage, and to evaluate the effectiveness, as well as pros and cons, of several non-lethal mitigation measures to deter giant armadillos from damaging beehives. In hopes of developing a win-win solution, we propose the implementation of a Honey Certification Scheme so that beekeepers and giant armadillos may not only coexist but thrive together.
\end{abstract}

Keywords: Apis mellifera, beekeeping, Cerrado, coexistence, human-wildlife conflict, wildlife damage

Tenha cuidado! Conflito entre apicultores e tatus-canastra e possíveis formas de coexistir

Resumo Danos causados pela vida silvestre constituem-se em uma das principais causas de conflitos humano-fauna (CHF) ao redor do mundo, ameaçando significativamente a conservação da biodiversidade e os meios de subsistência das pessoas. A compreensão dos mecanismos que sustentam tais danos é fundamental para combater o CHF e promover a coexistência. Neste artigo, fornecemos informações sobre o padrão e a magnitude do dano causado por tatus-canastra em apiários no Cerrado do Mato Grosso do Sul, Brasil. Com a colaboração de 10 associações apícolas, reunimos informações de 178 apicultores. Setenta e três por cento deles relatou danos às colmeias por tatus-canastra nos últimos cinco anos e $46 \%$ nos últimos 12 meses, resultando em perdas econômicas substanciais. Usamos uma combinação de relatos de apicultores e armadilhas fotográficas para caracterizar o padrão do dano e avaliar a efetividade, os prós e contras de algumas medidas de mitigação não-letais para impedir que os tatus-canastra danifiquem as colmeias. Na esperança de desenvolver uma solução onde todos os lados saiam ganhando, nós propomos a implementação de um esquema de certificação do mel para que apicultores e tatus-canastra possam não apenas coexistir, mas juntos prosperar.

Palavras-chave: apicultura, Apis mellifera, Cerrado, coexistência, conflito humano-fauna, danos causados pela vida silvestre 


\section{INTRODUCTION}

Human-wildlife conflict (hereafter, HWC) is undoubtedly a challenging and urgent conservation issue worldwide (Hodgson et al., 2020). One of its main causes is damage by wildlife, which threatens livelihoods and the mental well-being of people affected (Messmer, 2000). This often leads to retaliatory actions against the animals deemed responsible (Sifuna, 2005). HWC may also result in human-human disagreement about what should be done to remedy a situation (Redpath et al., 2015). In South America, several examples of HWC have been documented. The most emblematic is the predation of domestic livestock by wild cats such as jaguars (Panthera onca; Inskip \& Zimmermann, 2009), or by wild canids on domestic fowl (Bickley et al., 2019). However, conflicts with armadillos have also been reported. The most-studied armadillo, the nine-banded armadillo (Dasypus novemcinctus), damages both agricultural crops and gardens (Gammons et al., 2009). In Argentina, the large hairy armadillo (Chaetophractus villosus) and the six-banded armadillo (Euphractus sexcinctus) are reported to damage silo bags (Zufiaurre et al., 2019). In Brazil, the six-banded armadillo is also persecuted and sometimes killed by ranch workers in the Pantanal because cattle and horses can step in the armadillos' burrows and break their legs (Desbiez, 2007). Finally, the giant armadillo (Priodontes maximus) in the Chaco of Paraguay damages water storage structures (Weiler \& Núñez, 2012). In this study, we provide the first description of giant armadillo damage to apiaries in the Cerrado biome of Mato Grosso do Sul (MS), Brazil, and the resulting conflict with beekeepers.

The giant armadillo is the largest living cingulate, with adults measuring up to $1.5 \mathrm{~m}$ long and weighing up to $60 \mathrm{~kg}$ (Carter et al., 2016; Desbiez et al., 2019b). This species is naturally rare but widely distributed throughout 11 countries in South America, in habitats ranging from tropical forest to open savanna (Smith 2007; Abba \& Superina, 2010). This large myrmecophagous species has an extensive home range, is solitary, nocturnal, and fossorial in habits and can therefore easily go unnoticed by the local population (Eisenberg \& Redford,

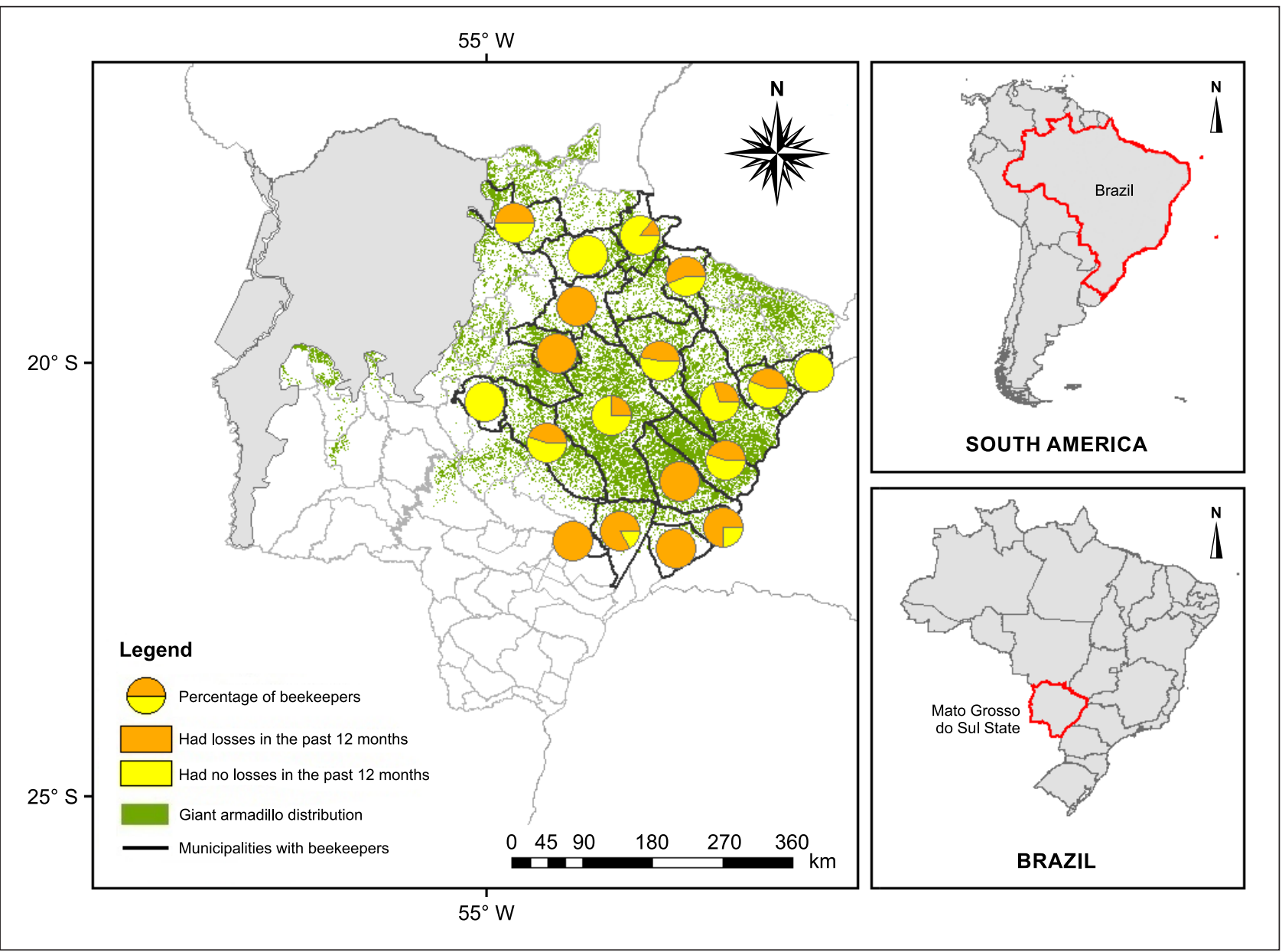

FIGURE 1. Prevalence of damage by giant armadillos (Priodontes maximus) to beehives in Mato Grosso do Sul state, Brazil from a survey conducted between July 2017 and October 2019: percentage of beekeepers who experienced damage by giant armadillos in the last year (orange) and those who did not (yellow). No conflict between giant armadillos and beekeepers was registered in the Pantanal, where giant armadillos also occur (grey shaded area). 


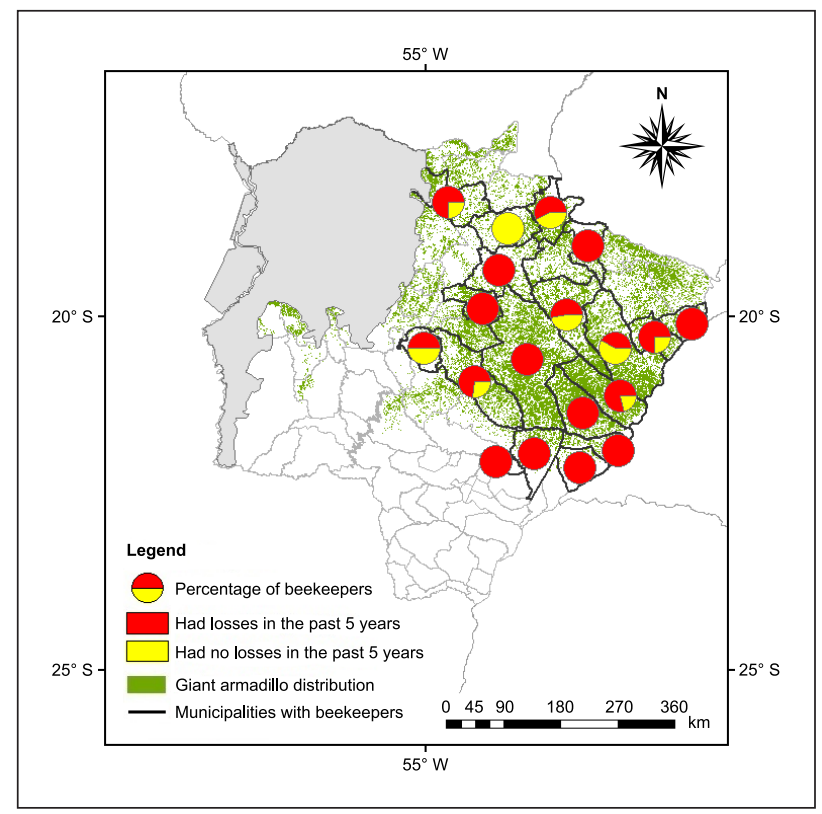

FIGURE 2. Prevalence of damage by giant armadillos (Priodontes maximus) to beehives in Mato Grosso do Sul state, Brazil from a survey conducted between July 2017 and October 2019: percentage of beekeepers who experienced damage by giant armadillos in the last five years (red) and those who did not (yellow). No conflict between giant armadillos and beekeepers was registered in the Pantanal, where giant armadillos also occur (grey shaded area).

1999; Silveira et al., 2009; Desbiez et al., 2020). Due mainly to habitat loss and hunting, the species is currently classified as "Vulnerable" (A2cd) on the IUCN Red List of Threatened Species (Anacleto et al., 2014).

Brazil's Cerrado is a highly diverse savanna ecosystem that provides critical habitat for many endemic and rare species (Klink \& Machado, 2005). The Cerrado is also home to the giant armadillo (Chiarello et al., 2015). Although it is considered one of the world's biodiversity hotspots, more than 50\% of Brazil's Cerrado has been transformed into pasture or agricultural lands planted with cash crops, and as little as $19.8 \%$ remains undisturbed (Green et al., 2019). Deforestation rates have been 2.5 times higher in the Cerrado than in the Amazon rainforest, and conservation efforts have been modest (Strassburg et al., 2017). Lemos and colleagues (2020) reported that giant armadillos can be found in highly human-modified Cerrado landscapes in central Brazil, but $83 \%$ of records occur in native vegetation. In Mato Grosso do Sul, however, the remaining areas of native Cerrado vegetation are highly fragmented and occur predominantly as small patches, with an average patch size of $9.05 \pm 0.70$ ha (Reynolds et al., 2016). In the better-preserved Pantanal region adjacent to the Cerrado, the median adult home-range area for giant armadillos is 2,510 ha (Desbiez et al., 2020), which suggests that individual giant armadillos in the Cerrado are likely to require several connected fragments to find the resources necessary for their survival.

Between April 2015 and July 2018, the Giant Armadillo Conservation Program launched a project to survey all native habitat fragments in over 500 micro watersheds throughout the Cerrado of Mato Grosso do Sul to map the distribution of the giant armadillo. During field work, we spoke with $>1000$ members of local communities to access native fragments on their land. During these informal conversations, it was reported that giant armadillos were adversely affecting beekeepers in several municipalities throughout the state. Beekeepers place their hives along the edges of the last fragments of native Cerrado vegetation so that their bees can be as close as possible to the native wild flowers. Unfortunately, these are also the fragments that sustain giant armadillos. Giant armadillos were reported to knock over and destroy beehives, but we also learned that beekeepers implemented a range of protection techniques to prevent this. Some of these strategies were non-invasive (e.g., fencing), whereas others were potentially lethal (e.g., poisoning). Beekeepers have reported retaliation against giant armadillos, which may explain why in some areas where our distribution models predicted the species should be present, we found no evidence of it. This leads us to believe that the conflict with beekeepers may be contributing to the local extinction of the species in some areas and should receive attention from conservationists.

Although damage does not necessarily translate into retaliatory behavior, several studies show that wildlife damage can affect people's evaluations of favorability towards a species and their willingness to protect it (e.g., Lindsley et al., 2005; Bickley et al., 2019). Historically, the science of Wildlife Damage Management has sought solutions so that humans and wildlife can coexist (Conover, 2002). This goal is usually achieved through a variety of approaches, for example by changing the behavior of the species causing the problem (Branco, 2018), by trying to reduce the vulnerability of the target (Marchini et al., 2011), or by influencing human behavior and attitudes so that people are more willing to tolerate the damage (Decker et al., 2012). For any of these approaches, the first and most basic step is problem definition: determining the species causing the loss, the pattern of the damage, and the magnitude of the problem (Vercauteren et al., 2010). Thus, in the present case, the first step to tackle is defining the threat that giant armadillos represent to the livelihood of beekeepers, and then explore potential approaches to alleviate this conflict. Hence, in this study we sought to: 1 . estimate the prevalence of damage by giant armadillos to beehives throughout their range in the Cerrado biome of Mato Grosso do Sul; 2. characterize the pattern 


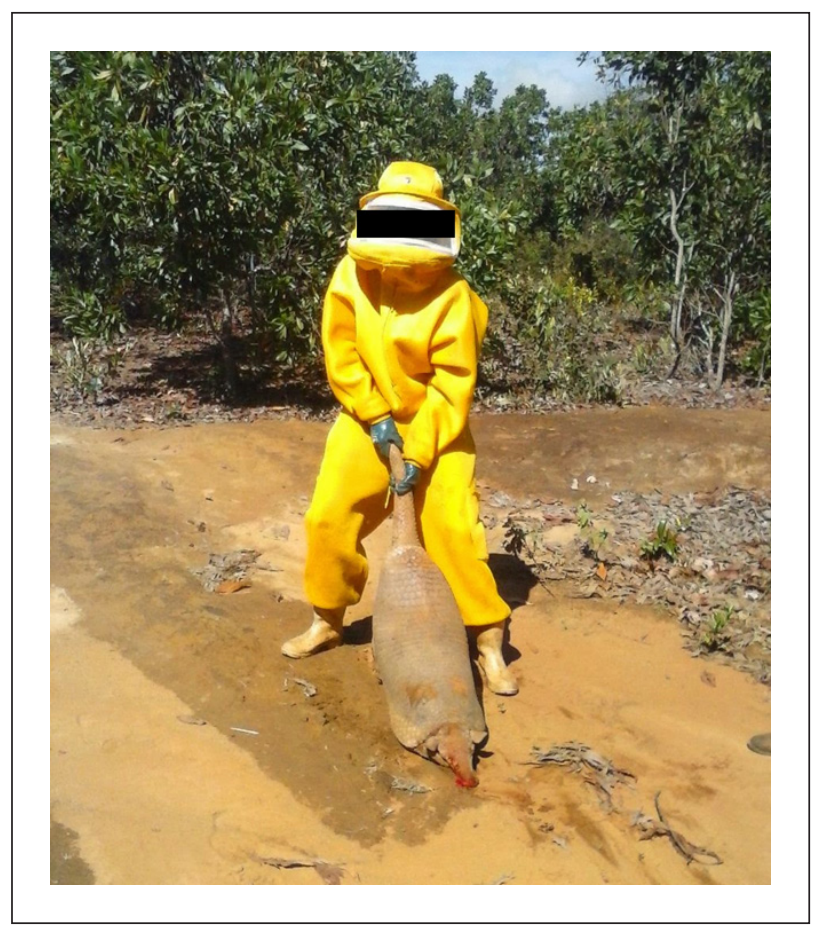

FIGURE 3. Beekeeper holding a dead giant armadillo (Priodontes maximus) killed in retaliation for the damage caused to his beehives. The picture was provided by a beekeeper who agreed with the anonymous disclosure of the content.

of damage and understand how the giant armadillo successfully predates the hives; and 3 . discuss the effectiveness of the different strategies that beekeepers are currently using to reduce damage. In addition, we explore solutions grounded not only in reducing the negative interactions between beekeepers and giant armadillos, but also in increasing positive relations between them.

\section{MATERIALS AND METHODS}

All of the 10 beekeeper associations found across the range of the giant armadillo in the Cerrado of Mato Grosso do Sul were consulted. In order to assess the prevalence of damage, and to calculate the financial cost of a damaged beehive, from July 2017 to October 2019 we asked the beekeeper associations to help us gather the following information: 1 . the total number of active associates; 2 . how many associates experienced damage by giant armadillos in the past five years and in the past 12 months; 3 . the amount of damage (in units of beehives) experienced by each of them in the two time frames (five years and the past 12 months), and 4 . the financial loss incurred from a damaged beehive unit.

To document giant armadillo predatory behavior and evaluate mitigation measures, we collaborated with beekeeping associations and conducted informal conversations with beekeepers in the region. We recorded the different mitigation strategies adopted by beekeepers and ranked their effectiveness in preventing giant armadillo predation as high, medium or low. Measures were also extensively discussed with beekeepers to understand their pros and cons. Effectiveness was considered to be high if every beekeeper who used the method prevented giant armadillo predation, medium if the measures worked only on some occasions, and low if they did not prevent giant armadillo raids in most apiaries.

In addition to the reports provided by beekeepers, we monitored the effectiveness of four mitigation methods (stands at less than $1.3 \mathrm{~m}$, fencing, pallets, securing hives to the stand) using camera traps. Between July 2017 and November 2019, 21 camera traps (Reconyx XP9, Holmen, USA) were placed on six properties at nine different apiaries, with the authorization of the owners. The camera traps were fixed a few meters away from the beehives to ensure full view of the hives and surroundings. They were set on 1080P HD video at 30 frames per second. To make sure that any animal predating the beehive would be detected, two cameras were placed around the same hives in six apiaries and three cameras in three apiaries. Cameras were left in the same apiary for at least three months.

\section{RESULTS}

A total of 178 beekeepers were consulted (FIG. 1, 2), of which 175 were men and three were women. Of these 178 individuals, 136 were members of the 10 beekeeping associations we consulted; the remaining 42 were non-member beekeepers who worked in neighboring municipalities. The number of hives per beekeeper ranged from four to 2,000, with an average of 230 ( $\pm 352 \mathrm{SD})$ hives per beekeeper. For $53 \%$ of these beekeepers, over half of their income came from beekeeping. Most of the beekeepers owned their own hives $(81 \%)$, while the rest cared for their own hives as well as someone else's, or cared for only someone else's hives. Thirty percent of beekeepers lived near or on the land where the honey was produced; $25 \%$ actually owned some of the land where they produced honey. In general, most of the hives were placed on land that did not belong to the beekeeper and required some form of transport to access.

\section{Prevalence and the cost of damage caused by giant armadillos to beehives}

Forty-six percent of beekeepers reported damage by giant armadillos in the past 12 months (FIG. 1), for a total of 1,036 damaged beehives in this period. In the past five years, $73 \%$ of associates experienced losses due to giant armadillo predation (FIG. 2), with approximately 6,265 destroyed beehives. The cost of a destroyed beehive was estimated between $R \$ 500$ and $R \$ 730$ (Brazilian reais) or 100 to 150 USD ( $1 R \$=0.20$ USD, 10 June 2020). The 
total financial loss due to giant armadillo predation on beehives in this region (using the minimum beehive cost estimate) was valued at $\mathrm{R} \$ 518,000$ in the past 12 months (or $\$ 103,600$ USD), and at over $\mathrm{R} \$ 3,000,000$ in the past five years (\$626,500 USD).

Giant armadillos usually toppled a single hive, but could topple up to five hives in the same night. One beekeeper who had not visited his hives for more than two weeks reported he had 120 hives toppled and destroyed. The beekeeper who claimed the most damage reported the loss of 460 hives ( $\mathrm{R} \$ 230,000 / \$ 46,000$ USD) during his 14 years as a beekeeper. Some beekeepers reported they have had to abandon specific areas where they produced honey due to the conflict. Some are aware of colleagues who gave up beekeeping altogether due to giant armadillo predation.

\section{Characterizing beekeepers' strategies to pre- vent beehive damage}

While some beekeepers adopted non-lethal mitigation strategies (described below), others used lethal methods to rid themselves of animals causing damage to hives, including poisoning and trapping (FIG. 3). Beekeepers reported that trapping was almost always unsuccessful, very time-consuming, and frustrating. Poisoning was usually successful as giant armadillos returned to feed on the fallen bee combs. Because the density of giant armadillos is very low (Desbiez et al., 2020), once the culprit was

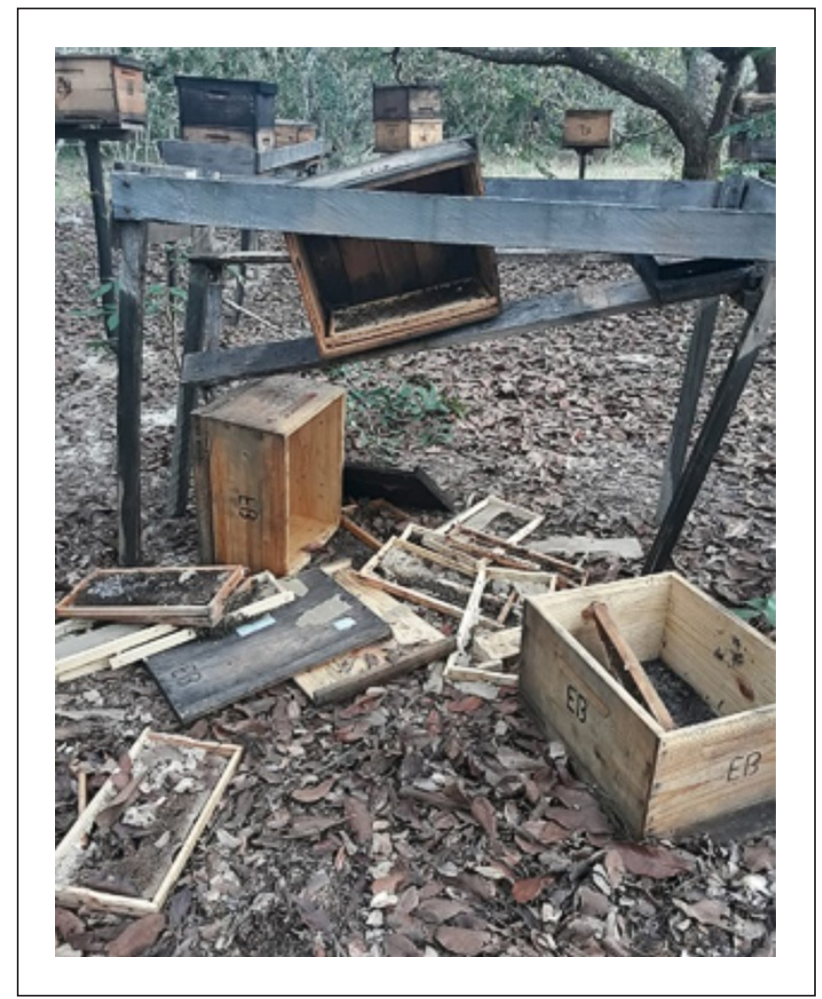

FIGURE 4B. Pattern of damage by giant armadillos (Priodontes maximus) to beehives in Mato Grosso do Sul state, Brazil.

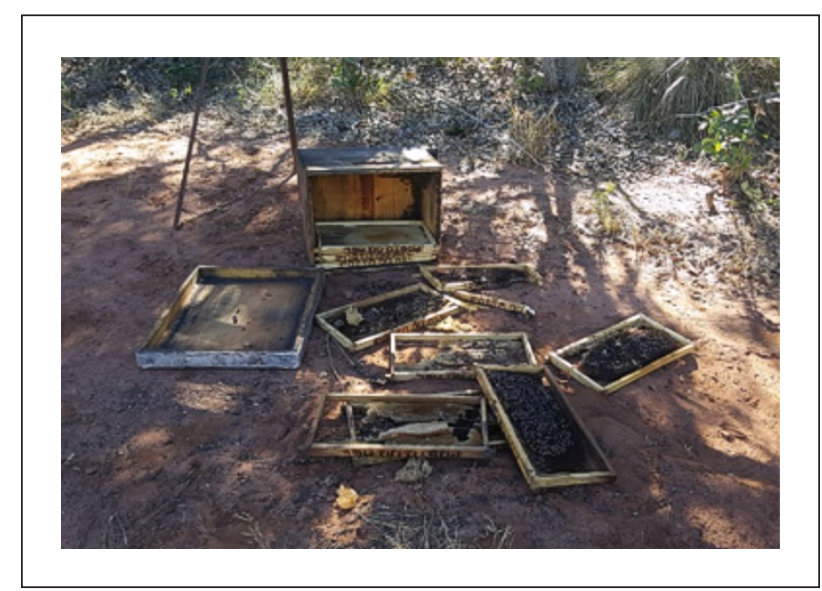

FIGURE 4A. Pattern of damage by giant armadillos (Priodontes maximus) to beehives in Mato Grosso do Sul state, Brazil.

killed, predation stopped for an average of three years according to beekeepers. Despite the extra financial and labor costs, some beekeepers voluntarily implemented non-lethal methods to prevent giant armadillo attacks. A total of 10 different methods to prevent giant armadillo predation were recorded and discussed with beekeepers and their representatives in the associations (TABLE 1).

\section{Characterizing the damage}

Camera traps recorded giant armadillo predation behavior on four occasions. Two of these involved hives that were on stands $<1.3 \mathrm{~m}$ high and were not secured to the stand (https://youtu.be/g_ncD5rxhto and https://youtu.be/aL68MeemPPY). In the third case a giant armadillo dug under a fence and predated hives that were on low stands (https://youtu. be/2h-GQpjKniI). Finally, on the last occasion a giant armadillo predated hives secured on a pallet placed on two tires (https://youtu.be/4lrj1OAZvH4).

The video records show that giant armadillos use their skull and nose rather than their claws to knock over beehives. They walk on their hind legs using their strong tail for balance and use their head to push over beehives as heavy as $35 \mathrm{~kg}$. They use their claws sometimes to hold on to structures to maintain balance. In Mato Grosso do Sul all bees are hybrids of European honey bees Apis mellifera mellifera with aggressive Africanized bees Apis mellifera scutellata. Videos show the armadillo's considerable resistance to bee stings, thanks to their thick skin and protective armor and scales. However, they were still inconvenienced by the bees, and we recorded images of giant armadillos rolling themselves on the ground and using their claws to rub the head, presumably as a means of getting rid of attacking bees.

Once a beehive was knocked on the ground the attacking giant armadillo proceeded to completely destroy it and dismantle all the frames (FIG. 4A, B). 


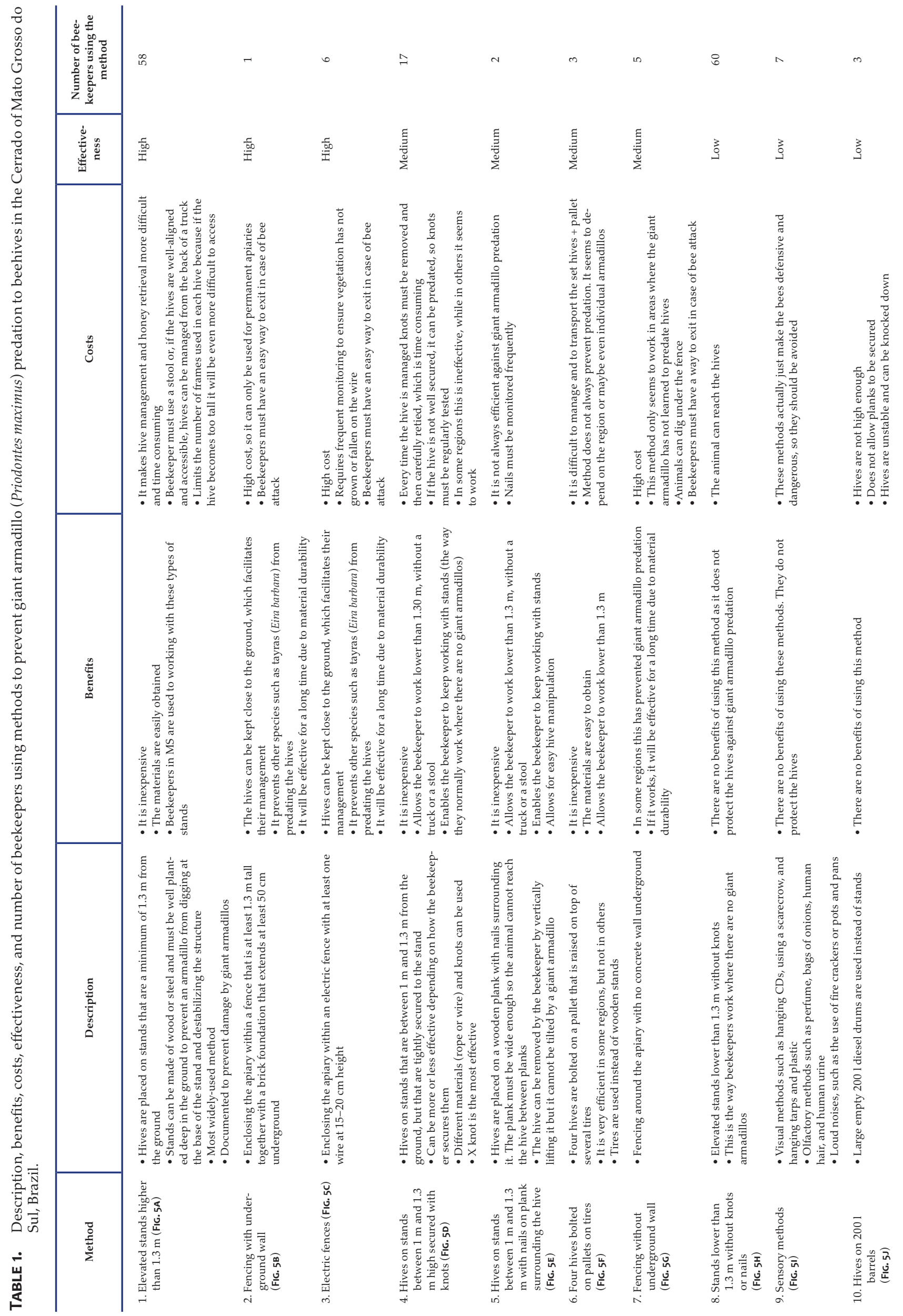



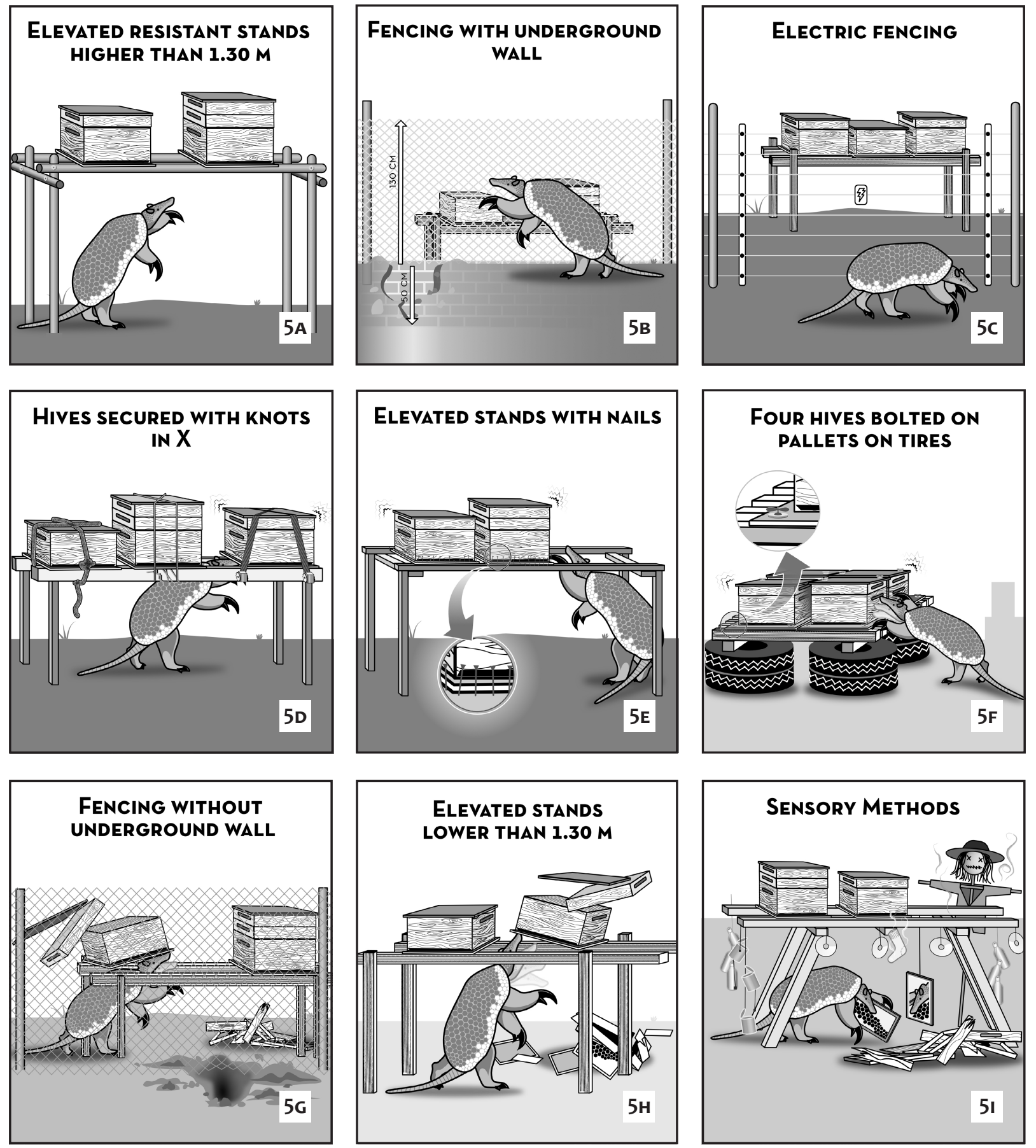

HIVES ON 200L BARRELS

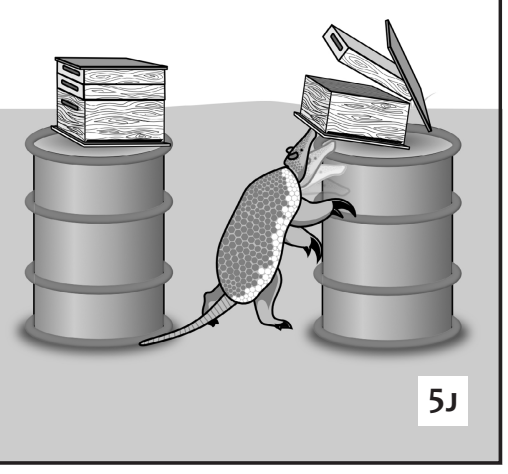

FIGURE 5. A-C: Highly effective methods, D-G: medium effective methods, and H-J: methods that never worked to prevent predation by giant armadillos (Priodontes maximus) to beehives, in the Cerrado of Mato Grosso do Sul state, Brazil. (A) Hives on stands a minimum of $1.3 \mathrm{~m}$ from the ground; (B) Aboveground fence with an associated underground wall; (C) Electric fence; (D) Hives on stands between $1 \mathrm{~m}$ to $1.3 \mathrm{~m}$ from the ground, but that are tightly secured to the stand; (E) Elevated stands on planks with the hive closely surrounded by nails; (F) Four hives bolted on pallets on tires; (G) Fencing without underground wall; (H) Elevated stands lower than $1.3 \mathrm{~m}$ and not secured; (I) Sensory methods; (J) Hives on 2001 barrels. 
This was often done over the course of several nights, including up to five nights in a row. Beekeepers observed that giant armadillos were not consuming honey but rather the bee larvae because they dismantled and fed on the brood comb rather than the honey frames. Beekeepers were particularly angered by the waste of honey, in addition to the destruction of their equipment.

Our camera traps further showed that other species forage on the fallen, destroyed frames during the day, including: tayra (Eira barbara), giant anteater (Myrmecophaga tridactyla), southern tamandua (Tamandua tetradactyla), six-banded armadillo (Euphractus sexcinctus), red-legged seriema (Cariama cristata), and bare-faced curassow (Crax fasciolata).

Beekeepers mentioned other mammals that they believe can cause damage to beehives, especially when the hives are kept lower to the ground. These include the six-banded armadillo, lesser grison (Galictis cuja), hooded capuchin monkey ( $\mathrm{Sa}$ pajus cay), black and gold howler monkey (Alouatta caraya), and tayra. Tayras usually gnaw and break a side of the hive without toppling it (FIG. 6). If they topple the beehive, they do not completely destroy it as the giant armadillo does. Sometimes, tayras, giant anteaters, and six-banded armadillos were blamed for giant armadillo damage. In addition to mammals, beekeepers reported damage by frogs, native bees, ants, and beetles, as well as termites (that attack the wood of the hive).

\section{DISCUSSION}

Conflict between beekeepers and native wildlife occurs in various regions of the world, ranging from black bears in the United States to honey badgers in South Africa (Maehr \& Brady, 1982; Otto \& Roloff, 2015; Carter et al., 2017). Testing and searching for adequate mitigation measures to promote co-existence with these species has been the focus of many studies (Maehr et al., 1982; Begg \& Begg, 2002). In our study we show that in some areas of Mato Grosso do Sul, giant armadillos have learned to predate beehives by knocking them over and destroying all the honeycombs to consume the bee larvae. We also compiled and rated the effectiveness of some of the mitigation methods used by beekeepers.

Most beekeepers in our study area experienced damage by giant armadillos at some point in their career as a beekeeper. However, it is not clear if giant armadillo predation of beehives is a widespread behavior throughout their South American range. The natural predation of a ground nest of stingless bees Trigona amalthea (Apidae: Meliponini) has been reported in the Serra do Divisor National Park, Acre, Brazil (Melo \& Nogueira, 2020). Nests of stingless bees are common, and are often low and accessible

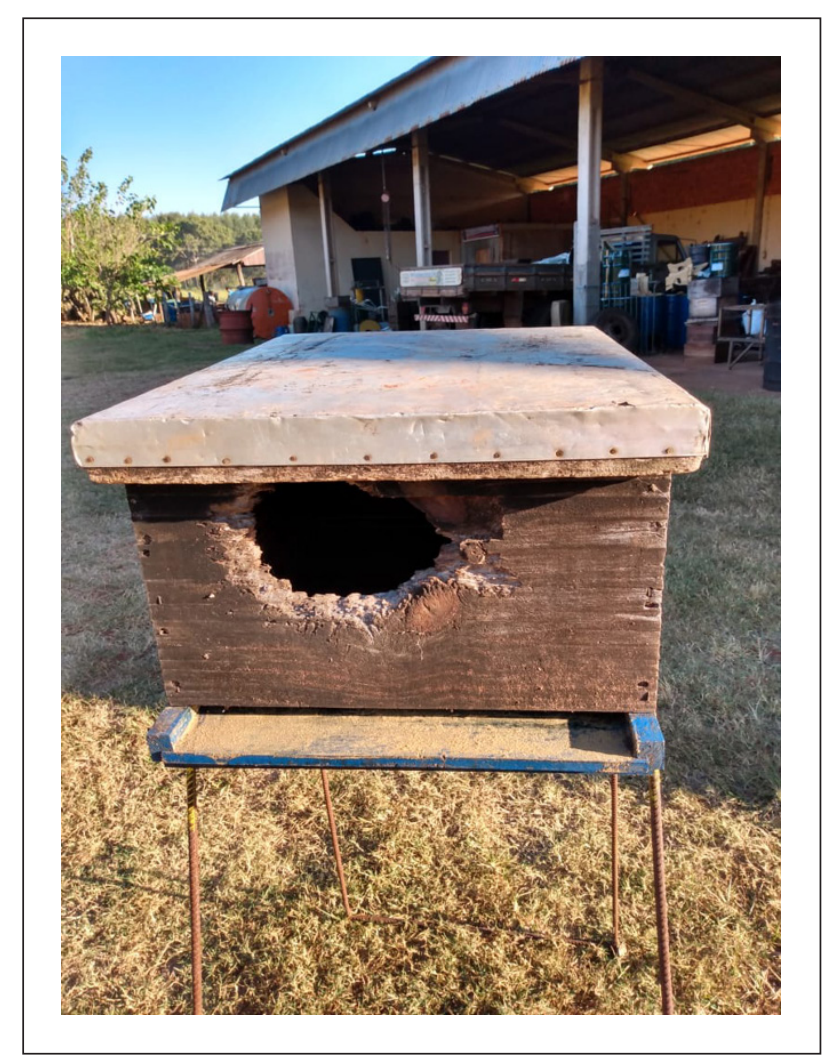

FIGURE 6. Pattern of tayra (Eira barbara) damage to beehives. Note that the pattern of damage is different from that of a giant armadillo (Priodontes maximus), see FIG. 4A, B.

to giant armadillos. They could therefore represent an important source of food for giant armadillos in the Amazon (Melo \& Nogueira, 2020). We consulted three beekeeper associations in the neighboring region of the Pantanal of Mato Grosso do Sul; there were no recorded issues of conflict with giant armadillos in the municipalities of Corumbá, Miranda, and Aquidauana. Beyond Mato Grosso do Sul, we received reports of beekeepers suffering attacks from giant armadillos in Minas Gerais state, Brazil (J. Magnino, pers. comm., 26 May 2019), Castelli, in the Chaco Province of Argentina (Y. Di Blanco, pers. comm., 30 August 2019), and, more recently, in Vichada, Colombia (C. Rojano, pers. comm., 24 March 2020). The problem could therefore be going unreported in other areas of the species distribution. It is possible that in more pristine environments giant armadillos do not need to resort to predation on artificial beehives, while in highly fragmented areas there might be less resources available, making beehives an attractive alternative. In support of this hypothesis, in Minas Gerais the attack took place in a highly altered landscape. Vichada is one of the most conserved departments of Colombia, but the attack took place in an area with a forestry plantation. In Castelli, in the Chaco, the hives were at the edge of a native forest patch surrounded by agricultural fields. 
Predation from giant armadillos may also be undetected if the wrong animal is blamed for beehive damage. For example, several of the beekeepers we spoke to reported that they thought giant anteaters were responsible for the attacks. That is because when they arrived at the apiary, they would find a giant anteater feeding on the honeycombs of a damaged beehive. Giant anteaters have been reported to predate a wild Apis mellifera colony (Miranda et al., 2003); however, we have never recorded them even attempting to predate man-made beehives. Furthermore, in areas where the giant armadillo is absent but the giant anteater is present, no attacks from giant anteaters have been registered. We therefore believe giant anteaters are being wrongly accused. Giant anteaters can be active during the day, especially on colder days (Camilo-Alves \& Mourão, 2006), while the giant armadillo is strictly nocturnal (Carter et al., 2016). A beekeeper will therefore find a giant anteater feeding off the fallen combs when he arrives at his apiary, which probably explains why giant anteaters have been accused. Diurnal activity may also explain why six-banded armadillos have been accused too.

Giant armadillo predation of beehives is very destructive and can affect the beekeepers' livelihoods. Beekeepers report with aggravation that there is nothing they can salvage, having to throw everything away after a predation event, which creates a feeling of frustration and waste. As mentioned in the RESULTS, several beekeepers commented that it bothered them that the armadillos do not even consume the honey. For all these reasons then, this conflict certainly creates a sense of resentment on the part of the beekeepers.

Because giant armadillos return to feed on fallen beehives for several nights in a row, they can easily be poisoned. Beekeeper associations mentioned eight beekeepers known to have killed giant armadillos. Only one individual openly admitted to doing this, but many beekeepers commented that they knew of colleagues who killed a giant armadillo in the past. As predation is usually done by a single animal, this solves the beekeeper's problem but it can have serious repercussions. Even in pristine habitats or protected areas, giant armadillo densities are always low, ranging from 1.27-7.65 individuals $/ 100 \mathrm{~km}^{2}$ (Noss et al., 2004; Silveira et al., 2009; Aya-Cuero et al., 2017; Desbiez et al., 2020). Therefore, we can assume densities will be even lower in highly degraded areas such as the Cerrado of Mato Grosso do Sul. Giant armadillos have low population growth rates (Carter et al., 2016; Desbiez et al., 2019a). Thus, the loss of a single animal in the fragmented Cerrado due to poisoning could precipitate local extinctions. In addition, many other species of animals that also forage on the predated beehives may be poisoned too.

Aside from poison, beekeepers who are victims of giant armadillo damage have a range of non-lethal

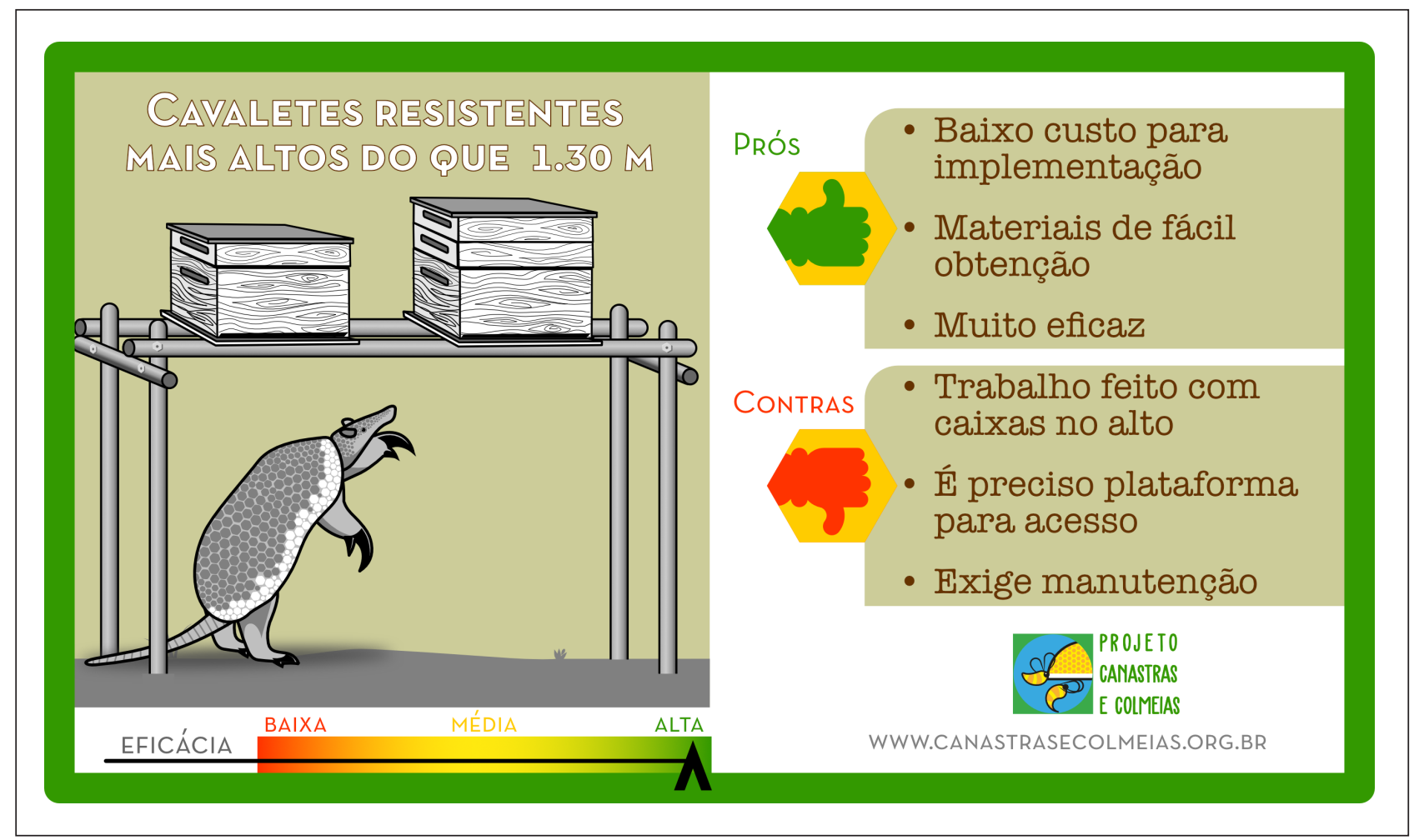

FIGURE 7. Example of an image sent by WhatsApp ${ }^{\circledR}$ to share mitigation strategies with beekeepers to prevent giant armadillo (Priodontes maximus) predation. 


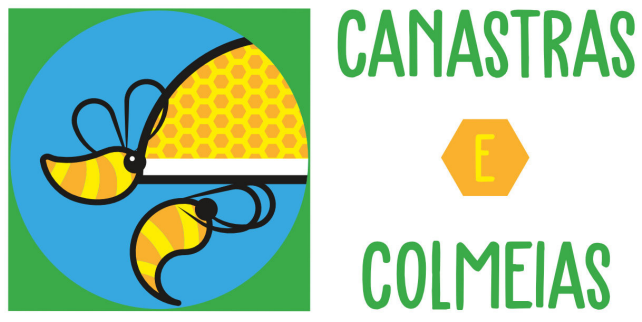

O PRODUTOR DESTE MEL PROTEGE 0 TAIU-GANAATRA WWW.CANASTRAECOLMEIAS.ORG.BR

FIGURE 8. Logo that beekeepers can put on their product label if they produce honey within the giant armadillo's (Priodontes maximus) range and employ highly effective methods to prevent giant armadillo attacks on their beehives.

techniques available to them. However, these methods mean he/she will incur an extra monetary or labor cost. Our study is essential to better understand giant armadillo behavior relative to beehives so that effective techniques used by some beekeepers can be shared and promoted to reduce apiary losses. Currently, the most effective and cheapest method is to elevate the hives on stands at least 1.3 $\mathrm{m}$ high. Some of the techniques used by the beekeepers are similar to those used to prevent attacks from bears in the United States, such as electric fences (FIG. 5C; Maehr et al., 1982), and those used against honey badgers in South Africa, where hives are also fastened to stands (FIG. 5D-G; Begg \& Begg, 2002). We are currently developing a "Coexistence guide" for beekeepers in the study area. In this manual, each method is illustrated, and its pros and cons discussed. We formatted and created a version so it can easily be shared among beekeepers on social media and via communication tools such as WhatsApp ${ }^{\circledR}$ (FIG. 7). This material is not an exhaustive list and will be constantly updated as new techniques are used and tested.

\section{Future directions to promote coexistence between giant armadillos and beekeepers}

Human-wildlife interactions span a broad conflict-to-coexistence continuum (Frank, 2016). Coexistence implies not only "to exist in the same time and space" or to tolerate the species, but also suggests some level of harmony in interactions (Marchini et al., 2019), with both sides' interests being satisfied (Frank, 2016). The mitigation methods discussed here can reduce damage to beehives but also require extra time, labor, and financial investment from the beekeepers. Adoption could fail to alleviate conflict if the additional costs and efforts of implementing these techniques lead to resentment towards the species (Kansky et al., 2014). It is therefore essential to find alternatives for beekeepers not only to manage giant armadillo attacks but also to improve their livelihoods and benefit from the species' presence.

In seeking to turn this conflict into a positive interaction with giant armadillos, we are incorporating beekeepers as partners in the planning and implementation of a certification system for their honey (https://www.canastrasecolmeias.org.br). The same approach has been used to promote coexistence with other species considered problematic. For example, "Elephant-Friendly Honey" has successfully reduced crop-raiding by elephants and created an economic boost to rural communities in Kenya (see https://www.savetheelephants.org/). The "Dolphin Safe Certification Scheme" is one of the most successful and well-known certification schemes for wildlife protection. This system monitors more than 800 companies in 76 countries to ensure that tuna fish are caught by methods that do not harm dolphins, and protect the marine ecosystem. Through the program, dolphin deaths in tuna nets have declined by 99\% since 1990 (see https:// www.fisheries.noaa.gov/national/marine-mammal-protection/dolphin-safe-certification). Through the "Giant Armadillo-Friendly Honey" certification program we will encourage best practices, generate a more environmentally-sustainable activity, and add value to the honey produced. The initiative will share with beekeepers the different mitigation strategies available to them, and how to implement them, while also providing market opportunities through new partnerships and communication in the media to provide visibility to "Giant Armadillo-Friendly Honey". Certification will also highlight the sustainable practices that beekeepers commonly use, such as fire management, habitat conservation, and absence of chemical treatments. Thus, through participatory workshops and discussions with beekeeper associations, we are creating a set of standards for certification. At first, the certification will be tested for Mato Grosso do Sul but we hope to expand the scale of the project as needed. Beekeepers who abide by the standards will be provided with a certificate and be able to put a specific logo on their produce that will recognize that the beekeeper protects giant armadillos (FIG. 8). The Wildlife Friendly Enterprise Network (WFEN) has been pioneering the use of sustainability standards for wildlife around the world since 2007, and we are currently collaborating with them on this project. Our hope is that, thanks to the certification, beekeepers and giant armadillos may have the opportunity to live in peace with each other, and the presence of giant armadillos near beehives will become a benefit rather than a problem. 


\section{ACKNOWLEDGEMENTS}

We would like to acknowledge all beekeeper associations (AACA-Associação Água Clarense de Apicultores, UNILESTE-Associação Regional de Apicultores da Costa Leste, ATLA - Associação Treslagoense de Apicultura de MS, AAPISEL - Associação de Apicultores de Selvíria, ABA - Associação Brasilandense de Apicultores, APIACRI - Associação dos Apicultores de Costa Rica, AAC-Associação dos Apicultores de Coxim, APIANG-Associação dos Apicultores de Angélica, APINOVA - Associação de Apicultores de Nova Andradina, APISUL-Associação dos apicultores de Chapadão do Sul) that were very helpful and quick to provide us with all the information we requested. In addition, thank you to the land owners that allowed us to test mitigation methods on their property. Finally, we would like to acknowledge all beekeepers, especially Davi, Elizeu, and Adriano Adames who gave us their precious time to teach us everything about the beekeeping universe and also provided their hives so we could test mitigation methods. Nina Attias, Andrew Noss, Jim Loughry, and two anonymous reviewers reviewed and improved this manuscript. All the art for this project was created by Ronald Rosa. The Whitley Fund for Nature, Houston Zoo, Boticário Foundation, and the Zoological and Botanical Garden Wilhelma in Stuttgart are funding this ongoing work.

\section{REFERENCES}

Abba, A. M. \& M. Superina. 2010. The 2009/2010 armadillo Red List assessment. Edentata 11: 135-184. https://doi.org/10.5537/020.011.0203

Anacleto, T.C.S., F. Miranda, I. Medri, E. Cuéllar, A.M. Abba \& M. Superina. 2014. Priodontes maximus. The IUCN Red List of Threatened Species 2014: e. T18144A47442343. https://dx.doi.org/10.2305/IUCN. UK.2014-1.RLTS.T18144A47442343.en. Downloaded on 26 May 2020.

Aya-Cuero C., A. Rodríguez-Bolaños \& M. Superina. 2017. Population density, activity patterns, and ecological importance of giant armadillos (Priodontes maximus) in Colombia. Journal of Mammalogy 98: 770-778. https://doi.org/10.1093/jmammal/gyx006

Begg, K. \& C. Begg. 2002. The conflict between beekeepers and honey badgers in South Africa: a Western Cape perspective. The Open Country 4: 25-36.

Bickley, S.M., F.G. Lemos, M.P. Gilmore, F.C. Azevedo, E.W. Freeman \& N. Songsasen. 2019. Human perceptions of and interactions with wild canids on cattle ranches in central Brazil. Oryx 53: 1-8.

Branco, P.S. 2018. The elephants of Gorongosa: an integrated approach to conservation and conflict mitigation in the shadow of the war. Doctoral Thesis, University of Idaho, Moscow. 89 pp.
Camilo-Alves, C.S.P. \& G.M. Mourão. 2006. Responses of a specialized insectivorous mammal (Myrmecophaga tridactyla) to variation in ambient temperature. Biotropica 38: 52-56.

Carter, S., T. du Plessia, A. Chwalibog \& E. Sawosz. 2017. The honey badger in South Africa: biology and conservation. International Journal of Avian and Wildlife Biology 2: 55-58. https://doi.org/10.15406/ ijawb.2017.02.00016

Carter, T.S., M. Superina \& D.M. Leslie. 2016. Priodontes maximus (Cingulata: Chlamyphoridae). Mammalian Species 48: 21-34. https://doi.org/10.1093/mspecies/ sew002

Chiarello, A.G., F. Röhe, F.R. Miranda, G.M. Mourão, K.F.M. Silva, S.M. Vaz \& T.C.S. Anacleto. 2015. Avaliação do risco de extinção de Priodontes maximus (Kerr, 1792) no Brasil. Série Estado de Conservação da Fauna Brasileira 2: 209-222.

Conover, M.R. 2002. Resolving human-wildlife conflicts: the science of wildlife damage management. CRC Press, New York. 440 pp. https://doi.org/10.1201/ 9781420032581

Decker, D.J., S.J. Riley \& W.F. Siemer. 2012. Human dimensions of wildlife management. The Johns Hopkins University Press, Baltimore, Maryland. 304 pp.

Desbiez, A.L.J. 2007. Wildlife conservation in the Pantanal: habitat alteration, invasive species and bush meat hunting. Doctoral Thesis, University of Kent, Canterbury. 216 pp.

Desbiez, A.L.J., G.F. Massocato \& D. Kluyber. 2019a. Insights in giant armadillo (Priodontes maximus Kerr, 1792) reproduction. Mammalia 84: 283-293. https:// doi.org/10.1515/mammalia-2019-0018

Desbiez, A.L.J., G.F. Massocato, D. Kluyber, C.N. Luba \& N. Attias. 2019b. How giant are giant armadillos? The morphometry of giant armadillos (Priodontes maximus Kerr, 1792) in the Pantanal of Brazil. Mammalian Biology 95: 9-14. https://doi.org/10.1016/j. mambio.2018.12.007

Desbiez, A.L.J., G.F. Massocato, D. Kluyber, C.N. Luba \& N. Attias. 2020. Spatial ecology of the giant armadillo (Priodontes maximus) in midwestern Brazil. Journal of Mammalogy 101: 151-163. https://doi. org/10.1093/jmammal/gyz172

Eisenberg, J.F. \& K.H. Redford. 1999. Mammals of the Neotropics, Volume 3. The central Neotropics: Ecuador, Peru, Bolivia, Brazil. The University of Chicago Press, Chicago, Illinois. 624 pp.

Frank, B. 2016. Human-wildlife conflicts and the need to include tolerance and coexistence: an introductory comment. Society and Natural Resources 29: 738-743. https://doi.org/10.1080/08941920.2015. 1103388

Gammons, D.J., M.T. Mengak \& L.M. Conner. 2009. Translocation of nine-banded armadillos. HumanWildlife Interactions 3: 64-71.

Green, J.M.H., et al. 2019. Linking global drivers of agricultural trade to on-the-ground impacts on bio- 
diversity. Proceedings of the National Academy of Sciences 116: 23202-23208. https://doi.org/10.1073/ pnas. 1905618116

Hodgson, I., S. Redpath, C. Sandström \& D. Biggs. 2020. Conflict management to date: a review. Pp. 9-23 in: The state of knowledge and practice on human-wildlife conflicts (M. O'Neil \& J. Villat, eds.). Luc Hoffmann Institute, University of Aberdeen, U.K.

Inskip, C. \& A. Zimmermann. 2009. Human-felid conflict: a review of patterns and priorities worldwide. Oryx 43: 18-34. https://doi.org/10.1017/S003060530899030X

Kansky, R., M. Kidd \& A. Knight. 2014. Meta-analysis of attitudes toward damage-causing mammalian wildlife. Conservation Biology 28: 924-938. https://doi. org/10.1111/cobi.12275

Klink, C.A. \& R. B. Machado. 2005. A conservação do Cerrado Brasileiro. Megadiversidade 1: 147-155.

Lemos, F. G., A. N. Costa, F. C. Azevedo, C.E. Fragoso, M.C. Freitas-Junior \& E. C. Rocha. 2020. Surveying in highly-modified landscapes to document the occurrence of threatened species: a study of the giant armadillo Priodontes maximus in central Brazil. Oryx 54:133-139. https://doi.org/10.1017/S0030605317001867

Lindsley, P.A., J.T. Du Toit \& M.G.L. Mills. 2005. Attitudes of ranchers towards African wild dogs (Lycaon pictus): conservation implications on private land. Biological Conservation 125: 113-121. https://doi. org/10.1016/j.biocon.2005.03.015

Maehr, D.S. \& J.R. Brady. 1982. Florida black bear-beekeeper conflict: 1981 beekeeper survey. American Bee Journal 122: 372-375.

Maehr, D.S., J.R. Brady \& J. Polk. 1982. The bears and bees: seeking a solution. Florida Wildlife 35: 40-42.

Marchini, S., S. Cavalcanti \& R.C. Paula. 2011. Predadores silvestres e animais domésticos: guia prático de convivência. Instituto Chico Mendes de Conservação da Biodiversidade (ICMBio), Brasília. 45 pp.

Marchini, S., et al. 2019. Planning for coexistence in a complex human-dominated world. Pp. 414-438 in: Human-wildlife interactions: turning conflict into coexistence (B. Frank, J.A. Glikman \& S. Marchini, eds.). Cambridge University Press, Cambridge. https://doi.org/10.1017/9781108235730.022

Melo, T.N. \& D.S. Nogueira. 2020. Giant armadillo (Priodontes maximus Kerr, 1792; Cingulata: Chlamyphoridae) attacks nest of stingless bee Trigona amalthea (Olivier, 1789) (Hymenoptera: Apidae). Edentata 21: 38-41. https://doi.org/10.2305/IUCN.CH.2020. Edentata-20-1.6.en

Messmer, T.A. 2000. The emergence of human-wildlife conflict management: turning challenges into opportunities. International Biodeterioration and Biodegradation 45: 97-102. https://doi.org/10.1016/ S0964-8305(00)00045-7
Miranda, G.H.B. de, F.H. G. Rodrigues, I. M. Medri \& F.V. dos Santos. 2003. Giant anteater (Myrmecophaga tridactyla) beehive foraging at Emas National Park, Brazil. Edentata 5: 55.

Noss, A.J., R. Peña \& D.I. Rumiz. 2004. Camera trapping Priodontes maximus in the dry forests of Santa Cruz, Bolivia. Endangered Species Update 21: 43-52.

Otto, T.E. \& G.J. Roloff. 2015. Black bear exclusion fences to protect mobile apiaries. Human-Wildlife Interactions 9: 78-86.

Redpath, S.M., S. Bhatia \& J. Young. 2015. Tilting at wildlife: reconsidering human-wildlife conflict. Oryx 49: 222-225. https://doi.org/10.1017/S0030605314000799

Reynolds, J., K. Wesson, A. L.J. Desbiez, J. M. Ochoa-Quintero \& P. Leimgruber. 2016. Using remote sensing and random forest to assess the conservation status of critical Cerrado habitats in Mato Grosso do Sul, Brazil. Land 5: 12. https://doi.org/10.3390/land5020012

Sifuna, N. 2005. Providing compensation for damage caused by wildlife: a case study of Kenya with particular reference to elephants. Journal of Social Development in Africa 20: 7-39. https://doi.org/10.4314/ jsda.v20i1.23892

Silveira, L., A.T.A. Jácomo, M.M. Furtado, N.M. Torres, R. Sollmann \& C. Vynne. 2009. Ecology of the giant armadillo (Priodontes maximus) in the grasslands of Central Brazil. Edentata 8-10: 25-34. https://doi. org/10.1896/020.010.0112

Smith, P. 2007. Giant armadillo Priodontes maximus (Kerr, 1792). Mammals of Paraguay $N^{\circ}$ 6. In: Fauna Paraguay: handbook of the mammals of Paraguay. $<$ www. faunaparaguay.com/mammhb2.html $>$. Downloaded on 26 April 2020.

Strassburg, B.B.N., et al. 2017. Moment of truth for the Cerrado hotspot. Nature Ecology and Evolution 1: 1-3. https://doi.org/10.1038/s41559-017-0099

Vercauteren, K.C., R. A. Dolbeer \& E.M. Gese. 2010. Identification and management of wildlife damage. Pp: 232-269 in: The wildlife techniques manual (N.J. Silvy, ed.). Johns Hopkins University Press, Baltimore, Maryland.

Weiler, A. \& K. Núñez. 2012. Desafíos para la conservación del tatú carreta (Priodontes maximus) en el Chaco Paraguayo. Reportes Científicos de la FACEN 3: 5-13.

Zufiaurre, E., A.M. Abba \& D.N. Bilenca. 2019. Assessment of stakeholder perceptions of the damage to silo bags by vertebrate species in Argentina. Human Dimensions of Wildlife 24: 80-86. https://doi.org/ 10.1080/10871209.2019.1538434

Received: 3 June 2020; Accepted: 24 July 2020 